\title{
Sewerage cost recovery alternatives achievable in seoul
}

\author{
서울시 하수도요금 현실화 방안에 관한 연구
}

\author{
Oh, Hyuntaek ${ }^{1} \cdot$ Kim, Sungtae $^{2} \cdot$ Park, Wankyu $^{3} \cdot$ Park, Jooyang $^{4} \cdot$ Park, Kyoohong $^{5^{*}}$ \\ 오현택1 $\cdot$ 김성태 ${ }^{2} \cdot$ 박완규 $^{3} \cdot$ 박주양 $\cdot$ 박규홍 $5^{*}$
}

'Department of Accounting, Cheongju University · ${ }^{2}$ Department of Economics, Cheongju University · ${ }^{3}$ Department of Economics, Chung-Ang University

${ }^{4}$ Department of Civil and Environmental Engineering, Hanyang University · ${ }^{5}$ School of Civil and Environmental Engineering, Chung-Ang University

1청주대학교 회계학과 · ${ }^{2}$ 청주대학교 경제학과 · 3 중앙대학교 경제학과 · ${ }^{4}$ 한양대학교 건설환경공학과 · ${ }^{5}$ 중앙대학교 사회기반시스템공학부

\begin{abstract}
As sewerage systems have obsolete, as quality and service level standards increase, and as rain characteristics change, the sewerage utility authorities are challenged to develop cost recovery strategies that assure financial sustainability. In this study, we conducted scenario analysis to examine the effect of three alternatives of partial or full sewerage cost recovery in Seoul during 2014-30 periods. It turned out that the alternative 1 is optimal and recommended. According to alternative 1, we had better increase annually sewerage fee by $14.8 \%$ until 2020 and thereafter apply only the inflation rate in setting sewerage fee. It would gradually decrease the deficit after 2019. The accumulated deficit of 13 billion Won in 2030 was estimated.

We expect that this kind of analysis may provide useful informations to help sewage utility staffs, decision makers, and regulatory authorities understand, develop and implement ultimate full cost recovery strategy for many municipalities.
\end{abstract}

Key words : cost recovery, sewerage fee, financial sustainability, scenario analysis

주제어 : 요금 현실화, 하수도요금, 재정적 지속가능성, 시나리오 분석

\section{1. 서 론}

기후변화로 인한 강우특성의 변화로 최근 서울 도심지역의 침수가 빈발하고 있어 하수관로의 통 수용량을 증대하는 하수관로정비사업, 하수저류 시설 건설 등의 침수방지 대책이 시급하다. 또한 환경부의 더욱 엄격해지는 수질오염총량제, 총인 규제, 공공하수처리시설의 우천시 미처리 방류 하 수에 대한 규제 강화를 위한 간이공공하수처리, $\mathrm{CSOs}$ 대책 등에 대한 요구가 커져, 물재생센터의 방류수 수질에 대한 관리가 더욱 어려워지고 더 많은 재원 투자가 필요하다. 하지만, 서울시는 재

- Received 04 July 2014, revised 13 October 2014, accepted 15 October 2014.

${ }^{*}$ Corresponding author: Tel :+81-2-820-5886 Fax : +81-2-812-4284 E-mail : kpark@cau.ac.kr
원 부족으로 기존 하수도 시설에 대한 유지보수도 충분하게 이루어지지 못하고 있는 반면, 현행 하 수도요금 수준은 처리원가 수준에도 미치지 못하 고 있으며, 적절한 요금현실화 추진을 위해 원시 자산평가와 총괄원가의 재산정이 필요하며, 지방 공기업법에 따라 하수도사업의 지방공기업 회계 로 전환하기 위한 하수도재정의 자립기반을 마련 해야 할 시급한 상황에 처해있다.

서울시는 2005 년에 하수도 요금을 $35 \%$ 인상 한 이후, 2012년까지 하수도요금을 동결해 왔다. 하수도정비기본계획(Seoul Metropolitan Government, 2009)상 2009년 2020년까지의 기 간 중 12 조 1,550 억원 재원이 필요하지만 투자가 능 재원이 부족한 것으로 나타났는데, 2010년 기 
준 하수도사업 처리원가 대비 현실화율이 $37 \%($ 처리원가 775 원 $/ \mathrm{m}^{3}$, 평균요금 283 원 $/ \mathrm{m}^{3}$ )에 불 과하였다. 이에 2011년 8월 하수도 요금 현실화 계획을 수립함으로써 하수처리수준 향상, 재난 예방 목적의 하수도기반시설 확충 투자재원 마 련을 위한 연차별 사용료 인상 추진계획을 수립 하고, 1 단계인 2014년까지 $68 \%$ 의 요금현실화 계획을, 2 단계인 2020 년까지 $100 \%$ 요금현실화 계획을 수립하였다. 또한 2012년 1월 5일 '서울 특별시 하수도사용조례'를 개정하여 2012년부터 2014년까지 연차별 인상요금을 확정하고, 2012 년에 35\%, 2013년에 20\%, 2014년에 15\%를 인 상하였다. 그 결과, '2012년 하수도 총괄원가 산 정용역 보고서'(Korea Waterworks Management Institute, 2013)에 의하면, 2012년 하수 도 원가 대비 현실화율은 $52 \%$ 이고, 향후 5 개년 동안 요금현실화율 100\% 달성을 목표로 2015년 부터 2017년까지 매년 11.5\%씩 요금인상을 추 진하는 안을 제안하였다.

1990년대 초에 호주와 뉴질랜드에서 서서 히 발전한 발생주의에 입각한 복식부기 회계제 도 도입을 위한 법제화에 이어, 1999년에 미국 에서도 GASB 34(Governmental Accounting Standards Board Statement No. 34)가 발 표, 시행되었다. 이는 정부부문도 민간기업처럼 일반회계 원칙에 입각한 회계처리와 재무보고서 를 작성 - 공개하는 제도로서 사회기반시설 자산 은 감가상각을 반영한 원가로 기록되어야 하지 만, 그 대안으로 자산의 유지와 교체를 위해 필 요한 예산계획을 수립하도록 하였다. GASB 34 는 사회기반시설에 대한 자산관리(Asset Management)를 요구하고 있으며, 이를 위해 지출 수요를 계획하기 위해 사회기반시설의 상태평가 (Condition Assessment)를 필요로 하는 등 많 은 정보를 필요로 하게 되었다. 상하수도 사용자 (고객)의 보호 및 재정적 지속가능성은 상하수도 요금을 관리하는 지방자치단체의 존립 목적 중 의 하나라고 할 수 있으며, 과거의 예산회계시 스템의 보완은 이를 도와주는 기반을 제공하고
있다. 캐나다 Federation of Canadian $\mathrm{Mu}-$ nicipalities and National Research Council(2006)에서도 상하수도요금의 적정화를 위한 보고서를 출간하여 지자체에서 이를 따르도록 권장하고 있다.

한편, $\operatorname{OECD}(2009)$ 는 상하수도분야의 궁극 적 투자재원 마련을 위해 3Ts(Taxes, Tariffs, Transfers)의 올바른 조합 비율을 찾도록 전략 적인 재정계획의 중요성을 강조한 바 있다. 특 히, 이 보고서는 상하수도요금(Tariffs)이 주민 이 감당할 수 있는 수준(Affordability)을 유지 하면서 지속가능한 비용회수(Sustainable Cost Recovery)를 달성하는 데에 중요한 역할을 하 며, 모든 주민을 대상으로 상하수도요금의 수준 을 인위적으로 낮게 유지하는 것을 강조하다보 면 결과적으로 저소득층을 더 어렵게 만들 개연 성이 있음을 경고하고 있다. $\mathrm{OECD}$ 의 권장에 따 라, 프랑스, 이탈리아, 덴마크 등의 유럽 여러 나라들이 상하수도요금의 적정화를 위한 정책 적 노력을 다각적으로 기울이고 있다(Labre, J, 2014; Zocchi, R., 2014; Hansen, A., 2014). François 등(2010)은 상하수도 요금의 현실화 를 위한 원인자부담원칙과 다른 환경관련 정책 시행의 원칙이 공존할 때 발생할 수 있는 갈등에 관해 논하였으며, van Dijk 등(2014)은 개발도 상국의 상하수도시설에 대한 재정지원 및 요금 현실화의 현안에 대해 사례연구를 통해 포괄적 인 고찰을 한 바 있다.

우리나라도 2004년에 지방분권특별법을 공 포하여 복식부기 도입에 관한 최초 규정을 제정 하였고, 2005년 지방재정법 개정을 통해 새로 운 회계제도에 대한 도입근거를 마련하여, 시행 시기를 2007년으로 규정하였다. 2008년 12월 에 지방자치단체 재무회계 운영규정으로 변경, 운영되다가 현재는 2013년에 개정된 '지방자치 단체 재무회계규칙'으로 운용되고 있다. 한편, 1969년 제정된 지방공기업법은 여러 차례의 개 정을 거쳐 2005년 지방공기업 시행령 개정시 하 수도사업 1 일 처리능력 1만5천톤 이상이면 지방 
공기업으로 전환하여 지방공기업 회계규칙을 준 수하도록 하고 있으며, 안전행정부는 2013년 10 월에 지방공기업법 일부 개정을 위한 입법예고 에 의해 하수도사업의 경우 기존 처리용량기준 을 없애고 지방직영기업으로 사업추진이 가능한 범위의 확대를 추진하고 있다. 서울시는 특별회 계로 운영하고 있는 하수도사업을 2015년에 지 방직영기업으로 전환할 계획이다(Seoul Metropolitan Government, 2014). Kang(2012) 와 $\operatorname{Han}(2009)$ 은 각각 지방공기업의 현황, 문제 점, 과제 및 지방공기업 경영혁신의 성과와 과제 에 대해 제시하였으나, 지방공기업의 가장 큰 부 분을 차지하는 상하수도 분야의 특화된 전문성 측면에서의 고찰이 미흡한 편이다. Jeong et al( (2012)은 지방상수도서비스의 비용과 요금의 영 향요인으로 공급적 요인, 수요적, 요인, 재정/제 도적 요인이 고루 영향을 미치는 것으로 보고하 였다. 하지만, 수도요금과 달리 하수도요금의 적 정성에 관한 학술적 연구는 거의 이루어지지 않 은 듯하다. 한편, 대한상하수도학회와 한국물환 경학회는 과거 10 여년 동안 다양한 세미나, 포럼 등을 통해 상하수도요금 현실화에 관련된 발제 와 토론의 장을 마련한 바 있으나, 학술전문가와 정책결정자의 긴밀한 협조와 소통을 통한 성공 적이고 실제적인 정책실현으로 이어지지는 못한 것으로 보인다. 이러한 한계상황에서, 회계학 및 경제학 분야와 상하수도공학의 전문가가 공동으 로 수행한 서울시의 하수도요금 현실화 및 하수 도요금체계 개편을 위한 연구 결과 중에서 서울 시 하수도요금 현실화에 대한 부분만을 본 논문 에 제시하고자 한다.

2012년 2014년 서울시 하수도요금의 급격 한 인상이 이루어져 2014년 요금현실화율 $72 \%$ 를 예상하는 상황에서, 본 연구에서는 2030년까 지의 하수도요금 적정화를 위한 대안 분석을 통 해 서울시의 하수도사업 재정효율화를 위한 정 책방향에 도움이 되는 결과를 제시하고자 한다. 첫 번째 대안은 2020년까지 하수도요금을 $100 \%$
현실화시키고 그 이후 2030년까지 물가상승률 만큼씩 요금을 인상하는 것이며, 두 번째 대안은 2030년에 하수도요금을 $100 \%$ 현실화하는 안이 며, 세 번째 대안은 현재로부터 2030년까지 물 가인상률만큼씩 하수도요금을 인상하는 것이다. 본 연구의 결과로서 하수도사업 관련 수지개선 을 위한 제언을 포함하였다.

\section{2. 연구방법}

\section{1 총괄원가 산정기준}

서울시 하수도요금의 총괄원가 산정을 위해 자산평가와 감가상각비, 유지관리비를 추정하 고, 원인자부담금 및 공사부담금, 그리고 차입금 상환액을 포함하도록 하였다 (각 세부비용의 추 정 결과는 논문에 수록되지 않음. 서울시(2014) 보고서 참조 요망). 서울시 하수도시설과 관련된 미래 투자액은 2009년에 작성된 2020년까지의 하수도정비기본계획의 재정분석 자료의 내용을 사용하였다. 2021년 2030년 사이의 투자액 은 하수도정비 기본계획(2009)에 제시되어 있지 않으므로, 2020년 투자금액에 대하여 2011년 2013년 소비자물가지수의 평균값인 2.5\% 만큼 씩 매년 증가하여 투자된다고 가정하였다. 하수 도정비와 관련된 투자금액은 대부분 설비 및 구 축물일 것이므로, 투자액에 대한 추가 감가상각 비는 30 년을 기준으로 한 정액법을 적용하여 계 산하였다.

서울시 하수도시설의 자산평가와 감가상각비 추정 결과 2014년부터 2030년까지 약 17 조 490 억원의 투자금액이 지출될 것으로 예상되며, 이 에 따른 내용연수 30 년 기준 정액법에 의한 감 가상각비는 약 5 조 2,069 억원이 추가 계상될 것 으로 예상되었다.

유지관리비의 추정을 위해 기본적으로 ' 2012 년도 서울특별시 하수도 총괄원가 산정 용역'자 료를 기초로 하였다. 인건비는 고정비로 볼 수 있으나, 2011년 2013년 소비자물가지수 평균 값 $2.5 \%$ 를 적용하여 안정적으로 증가한다고 가 
정하였다. 또한 2015년 하수도 지방직영기업 설 립후 조직구성의 최소한의 인원증가 요인을 고 려하여 2015년부터 120 백만원 증가되는 것으로 가정하였다(단, 인건비는 향후 인력수급계획에 따라 변동될 가능성 있음). 운영비는 현재의 운 영규모(연간조정량 $1,130,039$ 천 $\mathrm{m}^{3}$ )가 유지된 다는 가정하에 2011년 2013년 소비자물가지 수 평균값 $2.5 \%$ 를 적용하여 추정하였으나 변동 비 성격인 운영비는 연간조정량의 변동에 따라 증감될 가능성이 있다. 물재생센터의 2012년 운 영비용은 총 1,549 억원이나, 이 금액 중 신설개 량으로 사용된 비용이 263억원이므로 이를 자산 으로 처리하여 실제 총 운영비는 신설개량비용 을 제외한 약 1,286 억원이라고 볼 수 있으므로, 이 금액을 기준으로 향후 물재생센터의 예상되 는 운영비용을 추정하였다.

원인자부담금 및 공사부담금 추정도 '2012년 도 서울특별시 하수도 총괄원가 산정 용역'자료 를 기초로 하였고, 최근 서울시 하수도사업 특별 회계 세입내역 및 예산자료를 반영하였다. 2013 년까지는 실제 세입내역을 그리고 2014년부터 는 추정된 원인자부담금 예산 금액을 반영하 였다. 원인자부담금은 경기변동에 민감하게 반 영하여 장기적인 전망을 추정하기 어려우므로, 2015년 이후에는 36,000 백만원이 일정하게 수 입되는 것으로 가정하였다. 원인자부담금은 매 년 지출액의 누적액으로 계산하되, 가동설비자 산의 감가상각비율만큼 상각하여 계산하였다. 총괄원가 산정시 자본기저에 포함되는 원인자부 담금 및 공사부담금은 자산의 감가상각비율만큼 상각하여 계산하도록 되어 있다. 공사부담금의 경우에도 금액 변동에 대한 구체적인 가정이 어 려우므로, 2010년과 2012년 평균금액이 2013년 이후에 동일하게 유지되는 것으로 가정하였다.

차입금 상환액 추정을 위해 ' 2012 년도 서울 특별시 하수도 총괄원가 산정 용역'자료를 기초 로 하였고, 가정의 단순화를 위하여 2012년도 의 자금상환액(111.23억원)과 이자지급액(1,255 백만원)이 일정하게 유지된다고 가정하였다. 하
수도 지방직영기업이 일정한 현금보유액 유지정 책을 실행할 경우, 현금흐름 변동에 따라 재정자 금 부족액에 대한 하나의 해결책으로 자금차입 을 고려할 수 있다. 추가적인 자금차입이 이루어 진다면, 일정금액의 자금유입(차입금액과 이자 수익)과 자금지출(상환금액과 이자지급)이 발생 하게 된다. 이자지급액은 최근 3 년 최고이율인 $3.03 \%$ 를 적용하였으며, 총괄원가를 계산하거나 재정적자 규모 산정시, 차입금 차입과 상환은 매 우 중요하지만, 이러한 사항은 정책적으로 결정 되므로 차입금에 대한 부분은 추가적으로 고려 하지 않았다. 총괄원가계산 시에는 2012년 이자 비용이 일정하게 유지된다고 가정하며, 재정적 자 규모를 추정할 때에는 차입금 내역을 반영하 지 않고 추정하였다.

\section{2 총괄원가의 추정}

현행 하수처리원가는 하수도요금 산정을 위 한 기초로서 총괄원가주의에 의한다('2012년도 서울특별시 하수도 총괄원가 산정'결과 참조). 총괄원가는 서비스를 공급하는데 소요되는 원가 에 가동설비 자산에 대한 공정투자 보수를 가산 한 금액이다. 즉, 운영비용인 영업비용(감가상 각비 포함)에서 지급이자를 제외한 영업외비용 을 더하고, 여기에서 관련사업 및 부대수입을 공 제한 적정원가에 적정투자보수액 $($ 요금기저 $\times$ 적 정투자보수율)을 더한 금액을 총괄원가로 산정 하고 있다.

\section{General cost $=$}

(Operating expenses+Capital expenses+ Non-operating expenses)-(Other operating revenue+Other operating revenue)

여기서, 영업비용: 인건비, 동력비, 약품비, 수선유지비, 민간위탁비, 감가상각비.

영업외비용: 하수도사업의 주된 영업활동외 에 발생하는 금융비용 등으로 하수관로 등 가동 설비자산을 교체, 정비시 신규 매설되거나 설치 
된 자산의 취득원가는 자산으로 계상하고, 폐기 되는 자산의 장부가액은 영업외비용 중 유형자 산제각손실로 계상함. 다만, 이자비용은 자본비 용에 포함함.

자본비용 : 타인자본에 대한 지급이자 + 자기자본에 대한 적정투자보수

자기자본보수 $=$ 요금기저 $\times$ 자기자본비율 $\times$ 4.76\% (2012년 적용비율로 일정)

자기자본비율 $=$ 자기자본 $/$ 총자본 $\times 100$

요금기저 $=$ 총가동설비자산 $-($ 기부채납자산 +시설분담금 + 원인자부담금 + 재 평가적립금 $)+($ 영업비용-감가상 각비 $) \times 2 / 12+$ 건설중인자산 $\times 1 / 2$ 기타영업수익 : 하수수익 이외의 영업활동으 로 발생한 수익으로 하수처리 부담금, 기타수수료 등을 합 산한 수익분

영업외수익 : 하수처리의 부수적 활동에서 발 생하는 수익으로 수입이자, 재 산임대수익, 불용품매각수익 등 을 합산한 수익분.

이 때, 영업외비용, 기타영업수익, 영업외수 익은 2010 2012년의 평균값이 향후에 지속적 으로 유지된다고 가정함.

\subsection{1 하수부과량 (연간조정량)}

하수부과량은 서울특별시 인구와 추정하수 량에 따라 변동하게 된다. '2012년 서울 서베 이(2013.6)'자료에 따르면 서울특별시 인구가 2010년 이후 약간의 감소추세를 보이나, 2012 년의 서울특별시 인구가 유지된다고 가정하였 다. 하수부과량은 상수도급수량과 지하수 사용 량을 합산하여 추정할 수 있다. '2012년 서울 서 베이(2013.6)'자료에 1인당 수돗물소비량이 감 소되고 있고, 생활쓰레기 발생량이 감소하고 있 다. 따라서 향후 추정하수량이 약간의 감소를 가 져올 것으로 예상되나, 그 추세를 쉽게 추정하기
어려우므로 2012년의 하수량이 유지된다고 가 정하였다. 따라서 연간 하수조정량 추정은 2012 년 수준인 $1,130,039$ 천 $\mathrm{m}^{3}$ 이 유지된다고 가정 하였다. 향후 인구감소 혹은 하수도요금 상승에 따른 하수발생량 감소 등 연간하수조정량의 추 정치가 감소 추세를 보인다면 총괄원가 및 재정 수입은 감소될 가능성이 있다.

\subsection{2 영업비용}

본청집행경비, 물재생센터유지비, 자치구집 행경비, 오수펌프장유지비 중 인건비는 고정비 성격으로 보고, 기타영업비용은 연간 하수조정 량에 따라 변동하는 변동비 성격으로 보았다. 인 건비는 하수도 지방직영기업 설립후 조직구성의 최소한의 인원증가요인을 고려하여 2015년부터 120 백만원 증가되는 것으로 가정하였으며, 인건 비는 향후 조직변경과 인력수급계획에 따라 변 동될 가능성이 있다. 또한 인건비와 기타 영업 비용은 2011년 2013년 평균 소비자물가지수 $2.5 \%$ 반영하여 일정하게 증가하는 것으로 가정 하였다. 감가상각비를 추정함에 있어, 2012년 말 현재 가동설비는 2012년 말 그대로 유지되는 것으로 가정하였다.

\section{2 .3 자본비용}

적정투자보수율은 2012년 말 기준인 4.76\% 가 유지되는 것으로 가정하였다. 차입금에 대한 이자비용은 서울특별시 차입금 차입 및 상환 장 기계획 자료가 구체적으로 수립되어 있지 않으 므로, 2012년 말 수준이 그대로 유지되는 것으 로 가정하였다. 부족한 자금을 충당하기 위해 차 입금을 지속적으로 차입할 경우, 자본비용 중 이 자비용의 큰 폭의 증가와 약간의 영업외수익(이 자수익)의 증가가 기대된다. 또한 차입금의 증가 로 자기자본비율이 낮아져 자기자본보수는 낮아 질 것으로 예상되므로 전체적으로 자본비용 및 총괄원가에 미치는 영향은 차입금 규모에 따라 유동적이다. 
자기자본비율은 하수도정비계획에 따른 투자 액과 여유 현금자금 유지정책에 따른 차입금 차 입 및 상환계획에 따라 변동될 수 있으나, 차입 금 관련 장기적 예측 자료가 주어져 있지 않으 므로 2012년 말 수준이 그대로 유지되는 것으로 가정하였다. 원인자부담금은 '2012년도 서울특 별시 하수도 총괄원가 산정 용역'자료를 기초로, 최근 서울시 하수도사업 특별회계 세입내역 및 예산자료를 반영하였다. 원인자부담금은 매년 추정 지출액의 누적액으로 계산하되, 가동설비 자산의 감가상각비율만큼 상각하여 계산하였다.

\subsection{4 기타}

영업외 비용, 기타 영업수익, 영업외 수익은 2010년과 2012년의 평균값이 유지된다고 가정 하였다.

그 결과, 2014년, 2020년, 2025년 및 2030 년에 예상되는 총괄원가는 Table 1과 같다.

하수도사업과 관련된 수입액은 영업수익(하 수도요금)이 가장 중요하지만, 그 외에도 중앙정 부보조금, 타회계(일반회계) 전입금, 원인자부 담금, 외부자금 차입 등에 따라 변동된다. 그러 나 하수도요금 외에는 다른 수입원에 대한 추정 이 쉽지 않은 상황이므로, 수입전망에 있어 하수 도요금의 변동이 가장 중요한 요소이다. 2014년 까지는 “서울특별시 하수도사용조례”에 따라 평

Table 1. Estimation of general cost

(unit: million won)

\begin{tabular}{|c|c|c|c|c|c|}
\hline & & 2014 & 2020 & 2025 & 2030 \\
\hline \multirow{3}{*}{ General cost } & Annual adjusted volume $\left(1000 \mathrm{~m}^{3}\right)$ & $1,130,039$ & $1,130,039$ & $1,130,039$ & $1,130,039$ \\
\hline & General cost & 932,030 & $1,362,992$ & $1,727,690$ & $2,108,971$ \\
\hline & Unit cost per $\mathrm{m}^{3}\left(\right.$ won $\left./ \mathrm{m}^{3}\right)$ & 824.8 & $1,206.1$ & $1,528.9$ & $1,866.3$ \\
\hline \multirow{6}{*}{ Operating expenses } & Total & 727,061 & 949,876 & $1,157,601$ & $1,392,622$ \\
\hline & Head office execution expenses & 45,836 & 53,291 & 60,294 & 68,217 \\
\hline & $\begin{array}{l}\text { Sewerage treatment plant } \\
\text { Maintenance expenses }\end{array}$ & 135,110 & 156,687 & 177,277 & 200,572 \\
\hline & Autonomies execution expenses & 74,074 & 85,903 & 97,192 & 109,964 \\
\hline & $\begin{array}{l}\text { Wastewater pump } \\
\text { maintenance expenses }\end{array}$ & 4,434 & 5,142 & 5,817 & 6,582 \\
\hline & Depreciation expense & 467,607 & 648,853 & 817,021 & $1,007,288$ \\
\hline \multirow{12}{*}{$\begin{array}{c}\text { Capital } \\
\text { expenses }\end{array}$} & Total & 226,960 & 435,107 & 592,080 & 738,339 \\
\hline & Interest expense & 1,255 & 1,255 & 1,255 & 1,255 \\
\hline & Cost of stockholders' equity & 225,705 & 433,852 & 590,825 & 737,084 \\
\hline & Reasonable cost of capital & $4.76 \%$ & $4.76 \%$ & $4.76 \%$ & $4.76 \%$ \\
\hline & The ratio of net worth & $98.56 \%$ & $98.56 \%$ & $98.56 \%$ & $98.56 \%$ \\
\hline & Fee base & $4,810,982$ & $9,247,704$ & $12,593,640$ & $15,711,205$ \\
\hline & Net operating equipment asset & $4,767,740$ & $9,197,533$ & $12,536,877$ & $15,646,983$ \\
\hline & Total operating equipment asset & $4,901,247$ & $9,405,737$ & $12,792,384$ & $15,935,946$ \\
\hline & Burden charge to the causer & 110,966 & 185,662 & 232,966 & 266,422 \\
\hline & Contributions for construction & 22,542 & 22,542 & 22,542 & 22,542 \\
\hline & Construction in progresses & 0 & 0 & 0 & 0 \\
\hline & Working fund & 43,242 & 50,170 & 56,763 & 64,222 \\
\hline Non-operating expenses & Total & 14,569 & 14,569 & 14,569 & 14,569 \\
\hline Other operating revenue & Total & 30,479 & 30,479 & 30,479 & 30,479 \\
\hline Non-operating revenue & Total & 6,081 & 6,081 & 6,081 & 6,081 \\
\hline
\end{tabular}


Table 2. Sewerage cost recovery strategies

\begin{tabular}{|c|c|c|c|c|}
\hline & 2010 & 2012 & 2013 & 2014 \\
\hline \hline Increase rate(\%) & - & 35 & 20 & 15 \\
\hline Average fee(won/ton) & 283 & 382 & 458 & 528 \\
\hline Amount of increase(won) & - & 99 & 76 & 70 \\
\hline Cost recovery rate(\%) & 37 & 49 & 59 & 68 \\
\hline $\begin{array}{c}\text { Expected profit } \\
(100 \text { million won) }\end{array}$ & 3,220 & 4,340 & 5,200 & 6,000 \\
\hline
\end{tabular}

Seoul open information (2012.5.28.), "Strategies on Sewerage Cost Recovery』

균 하수도요금 인상계획이 Table 2 와 같이 정해 져 있으므로 이를 준용하였다.

2015년 이후의 하수도요금 평균단가는 요금 현실화 방안에 따라 변동될 것으로 예상할 수 있 다. 본 연구에서는 Table 3 과 같은 3 가지 대안 에 대하여 수입전망을 추정하였다.

\section{3. 연구결과 및 고찰}

\section{1 하수도요금 현실화 방안}

\subsection{1 대안1 (2020년까지 100\% 현실화 이후 물 가상승률을 따름)}

대안1은 중장기 투자계획을 반영하여, 2020 년까지 하수도요금 $100 \%$ 현실화를 달성하고 그 이후에는 물가상승률에 따라 요금인상하는 안이 다. 물가인상률은 2011년 2013년 평균 소비 자물가지수 $2.5 \%$ 를 적용하였으며, 2020년 하 수도 사용료 수입이 2020년 추정된 총괄원가와 동일한 금액이 되도록(하수도요금 현실화 $100 \%$ 달성) 2020년까지 매년 하수도요금을 일정률 인 상하는 방안이다. Table 4에서 볼 수 있듯이, 2015년부터 2020년까지 매년 $14.76 \%$ 사용료 를 인상함으로써 2020년에 100\% 현실화를 달 성할 수 있다.

[대안1]에 따른 2014년부터 2030년 까지의 수입전망은 Table 5 와 같다. 2020년에 현실화 율 $100 \%$ 를 달성한 이후에는 지속적으로 하수도 요금의 현실화율이 떨어져, 2030년에는 현실화 율이 $82.73 \%$, 인상요인이 $20.88 \%$ 로 추정된다.
Table 3. Alternatives of sewerage cost recovery

\begin{tabular}{|c|c|}
\hline Altenative 1 & $\begin{array}{c}\text { Increasing sewerage fee depends on inflation } \\
\text { rate until 2030 after accomplishing sewerage } \\
\text { cost recovery rate up to 100\% until 2020 }\end{array}$ \\
\hline Altenative 2 & $\begin{array}{c}\text { Sewerage fee increase aims to reach up to } \\
100 \% \text { sewerage cost recovery until 2030 }\end{array}$ \\
\hline Altenative 3 & $\begin{array}{r}\text { Increasing sewerage fee depends on inflation } \\
\text { rate until 2030 }\end{array}$ \\
\hline
\end{tabular}

\subsection{2 대안2 (2030년까지 100\% 현실화)}

대안2는 2030년 하수도 사용료 수입이 2030 년 추정된 총괄원가와 동일한 금액이 되도록(하 수도요금 현실화 $100 \%$ 달성) 매년 하수도요금 을 일정률 인상하는 방안이다. 다음 Table 6에 서 볼 수 있듯이, 2015년부터 2030년까지 매 년 $8.21 \%$ 하수도 사용료를 인상함으로써 2030 년에 $100 \%$ 현실화를 달성할 수 있을 것으로 추 정된다.

[대안2]에 따른 2014년부터 2030년까지의 수 입전망은 Table 7과 같다.

\subsection{3 대안3 (2030년까지 물가상승률만 적용)}

향후 2030년까지 물가상승률에 따른 요금 인 상만을 반영하는 경우로, 물가인상률은 2011년 2013년 평균 소비자물가지수 2.5\%를 적용 하였다. 매년 현실화율은 낮아져 2030년에는 하수도요금 현실화율이 $42.0 \%$, 요금 인상요인 이 $138.1 \%$ 가 된다. [대안3]에 따른 2014년부터 2030년까지의 요금인상률과 현실화율, 그리고 수입전망은 본 논문에는 수록하지 않았다(서울 시(2014) 보고서를 참고).

\section{2 재정적자 규모 전망}

하수도사업과 관련된 지출전망과 총괄원가 추 정치, 그리고 대안별 수입전망에 기초하여 재정 적자 규모를 전망하였다. 재정적 규모를 전망함 에 있어서, 수입과 지출 전망을 현금기준을 적 용하여야 하지만 당해연도 미수입금액과 과년도 
Table 4. Increase rate and cost recovery rate of sewerage fee until 2030 based on alternative 1

\begin{tabular}{|c|c|c|c|c|c|}
\hline year & $\begin{array}{c}\text { Unit price of } \\
\text { full cost (Won) }\end{array}$ & $\begin{array}{c}\text { Unit price of } \\
\text { sewerage fee (Won) }\end{array}$ & $\begin{array}{c}\text { Increase rate of } \\
\text { sewerage fee }\end{array}$ & Cost recovery rate & Cause of increase \\
\hline 2014 & 824.8 & 528.0 & $115.28 \%$ & $64.02 \%$ & $56.21 \%$ \\
\hline 2015 & 890.4 & 605.9 & $114.76 \%$ & $68.05 \%$ & $46.94 \%$ \\
\hline 2016 & 948.0 & 695.4 & $114.76 \%$ & $73.35 \%$ & $36.33 \%$ \\
\hline 2017 & $1,016.9$ & 798.0 & $114.76 \%$ & $78.48 \%$ & $27.43 \%$ \\
\hline 2018 & $1,079.9$ & 915.8 & $114.76 \%$ & $84.81 \%$ & $17.91 \%$ \\
\hline 2019 & $1,143.2$ & $1,051.0$ & $114.76 \%$ & $91.93 \%$ & $8.77 \%$ \\
\hline 2020 & $1,206.1$ & $1,206.1$ & $114.76 \%$ & $100.00 \%$ & $0.00 \%$ \\
\hline 2021 & $1,269.6$ & $1,236.3$ & $102.50 \%$ & $97.38 \%$ & $2.69 \%$ \\
\hline 2022 & $1,333.6$ & $1,267.2$ & $102.50 \%$ & $95.02 \%$ & $5.24 \%$ \\
\hline 2023 & $1,398.1$ & $1,298.9$ & $102.50 \%$ & $92.90 \%$ & $7.64 \%$ \\
\hline 2024 & $1,463.2$ & $1,331.4$ & $102.50 \%$ & $90.99 \%$ & $9.90 \%$ \\
\hline 2025 & $1,528.9$ & $1,364.6$ & $102.50 \%$ & $89.26 \%$ & $12.03 \%$ \\
\hline 2026 & $1,595.1$ & $1,398.8$ & $102.50 \%$ & $87.69 \%$ & $14.04 \%$ \\
\hline 2027 & $1,662.0$ & $1,433.7$ & $102.50 \%$ & $86.27 \%$ & $15.92 \%$ \\
\hline 2028 & $1,729.4$ & $1,469.6$ & $102.50 \%$ & $84.97 \%$ & $17.68 \%$ \\
\hline 2029 & $1,797.5$ & $1,506.3$ & $102.50 \%$ & $83.80 \%$ & $19.33 \%$ \\
\hline 2030 & $1,866.3$ & $1,544.0$ & $102.50 \%$ & $82.73 \%$ & $20.88 \%$ \\
\hline
\end{tabular}

Table 5. Prospected profit based on alternative 1

\begin{tabular}{|c|c|c|c|c|}
\hline Year & $\begin{array}{c}\text { Annual adjustive } \\
\text { volume }\left(1,000 \mathrm{~m}^{3}\right)\end{array}$ & $\begin{array}{c}\text { Unit price of } \\
\text { sewerage fee(Won) }\end{array}$ & $\begin{array}{c}\text { Increase rate of } \\
\text { sewerage fee }\end{array}$ & $\begin{array}{c}\text { Sewerage profit } \\
\text { (Million Won) }\end{array}$ \\
\hline 2014 & $1,130,039$ & 528.0 & $115.28 \%$ & 596,661 \\
\hline 2015 & $1,130,039$ & 605.9 & $114.76 \%$ & 684,734 \\
\hline 2016 & $1,130,039$ & 695.4 & $114.76 \%$ & 785,807 \\
\hline 2017 & $1,130,039$ & 798.0 & $114.76 \%$ & $1,034,915$ \\
\hline 2018 & $1,130,039$ & 915.8 & $114.76 \%$ & $1,187,679$ \\
\hline 2019 & $1,130,039$ & $1,051.0$ & $114.76 \%$ & $1,362,992$ \\
\hline 2020 & $1,130,039$ & $1,206.1$ & $114.76 \%$ & $1,397,067$ \\
\hline 2021 & $1,130,039$ & $1,236.3$ & $102.50 \%$ & $1,431,994$ \\
\hline 2022 & $1,130,039$ & $1,267.2$ & $102.50 \%$ & $1,467,794$ \\
\hline 2023 & $1,130,039$ & $1,298.9$ & $102.50 \%$ & $1,504,489$ \\
\hline 2024 & $1,130,039$ & $1,331.4$ & $102.50 \%$ & $1,542,101$ \\
\hline 2025 & $1,130,039$ & $1,364.6$ & $102.50 \%$ & $1,580,653$ \\
\hline 2026 & $1,130,039$ & $1,398.8$ & $102.50 \%$ & $1,620,170$ \\
\hline 2027 & $1,130,039$ & $1,433.7$ & $102.50 \%$ & $1,660,674$ \\
\hline 2028 & $1,130,039$ & $1,469.6$ & $102.50 \%$ & $1,702,191$ \\
\hline 2029 & $1,130,039$ & $1,506.3$ & $102.50 \%$ & $1,744,745$ \\
\hline 2030 & $1,130,039$ & $1,544.0$ & $102.50 \%$ & \\
\hline
\end{tabular}


Table 6. Increase rate and cost recovery rate of sewerage fee until 2030 based on alternative 2

\begin{tabular}{|c|c|c|c|c|c|}
\hline year & $\begin{array}{c}\text { Unit price of } \\
\text { full cost (Won) }\end{array}$ & $\begin{array}{c}\text { Unit price of } \\
\text { sewerage fee (Won) }\end{array}$ & $\begin{array}{c}\text { Increase rate of } \\
\text { sewerage fee }\end{array}$ & Cost recovery rate & Cause of increase \\
\hline 2014 & 824.8 & 528.0 & $115.28 \%$ & $64.02 \%$ & $56.21 \%$ \\
\hline 2015 & 890.4 & 571.4 & $108.21 \%$ & $64.17 \%$ & $55.84 \%$ \\
\hline 2016 & 948.0 & 618.3 & $108.21 \%$ & $65.22 \%$ & $53.33 \%$ \\
\hline 2017 & 1016.9 & 669.0 & $108.21 \%$ & $65.79 \%$ & $51.99 \%$ \\
\hline 2018 & 1079.9 & 724.0 & $108.21 \%$ & $67.04 \%$ & $49.16 \%$ \\
\hline 2019 & 1143.2 & 783.4 & $108.21 \%$ & $68.53 \%$ & $45.93 \%$ \\
\hline 2020 & 1206.1 & 847.7 & $108.21 \%$ & $70.29 \%$ & $42.28 \%$ \\
\hline 2021 & 1269.6 & 917.3 & $108.21 \%$ & $72.25 \%$ & $38.40 \%$ \\
\hline 2022 & 1333.6 & 992.7 & $108.21 \%$ & $74.44 \%$ & $34.34 \%$ \\
\hline 2023 & 1398.1 & 1074.2 & $108.21 \%$ & $76.83 \%$ & $30.16 \%$ \\
\hline 2024 & 1463.2 & 1162.4 & $108.21 \%$ & $79.44 \%$ & $25.88 \%$ \\
\hline 2025 & 1528.9 & 1257.8 & $108.21 \%$ & $82.27 \%$ & $21.55 \%$ \\
\hline 2026 & 1595.1 & 1361.1 & $108.21 \%$ & $85.33 \%$ & $17.19 \%$ \\
\hline 2027 & 1662.0 & 1472.9 & $108.21 \%$ & $88.62 \%$ & $12.84 \%$ \\
\hline 2028 & 1729.4 & 1593.8 & $108.21 \%$ & $92.16 \%$ & $8.51 \%$ \\
\hline 2029 & 1797.5 & 1724.7 & $108.21 \%$ & $95.95 \%$ & $4.23 \%$ \\
\hline 2030 & 1866.3 & 1866.3 & $108.21 \%$ & $100.00 \%$ & $0.00 \%$ \\
\hline
\end{tabular}

Table 7. Prospected profit based on alternative 2

\begin{tabular}{|c|c|c|c|c|}
\hline Year & $\begin{array}{c}\text { Annual adjustive } \\
\text { volume }\left(1,000 \mathrm{~m}^{3}\right)\end{array}$ & $\begin{array}{c}\text { Unit price of } \\
\text { sewerage fee(Won) }\end{array}$ & $\begin{array}{c}\text { Increase rate of } \\
\text { sewerage fee }\end{array}$ & $\begin{array}{c}\text { Sewerage profit } \\
\text { (Million Won) }\end{array}$ \\
\hline 2014 & $1,130,039$ & 528.0 & $115.28 \%$ & 596,661 \\
\hline 2015 & $1,130,039$ & 571.4 & $108.21 \%$ & 645,652 \\
\hline 2016 & $1,130,039$ & 618.3 & $108.21 \%$ & 698,667 \\
\hline 2017 & $1,130,039$ & 669.0 & $108.21 \%$ & 856,035 \\
\hline 2018 & $1,130,039$ & 724.0 & $108.21 \%$ & 885,288 \\
\hline 2019 & $1,130,039$ & 783.4 & $108.21 \%$ & 957,979 \\
\hline 2020 & $1,130,039$ & 847.7 & $108.21 \%$ & $1,036,639$ \\
\hline 2021 & $1,130,039$ & 917.3 & $108.21 \%$ & $1,121,758$ \\
\hline 2022 & $1,130,039$ & 992.7 & $108.21 \%$ & $1,313,536$ \\
\hline 2023 & $1,130,039$ & 1074.2 & $108.21 \%$ & $1,421,390$ \\
\hline 2024 & $1,130,039$ & 1162.4 & $108.21 \%$ & $1,538,101$ \\
\hline 2025 & $1,130,039$ & 1257.8 & $108.21 \%$ & $1,664,394$ \\
\hline 2026 & $1,130,039$ & 1361.1 & $108.21 \%$ & $1,801,058$ \\
\hline 2027 & $1,130,039$ & 1472.9 & $108.21 \%$ & $1,948,943$ \\
\hline 2028 & $1,130,039$ & 1593.8 & $108.21 \%$ & $2,108,971$ \\
\hline 2029 & $1,130,039$ & 1724.7 & $108.21 \%$ & \\
\hline 2030 & $1,130,039$ & 1866.3 & $108.21 \%$ & \\
\hline
\end{tabular}


이월수입금액은 고려하지 않았다. 정책적 판단 이 필요한 중장기적 하수도정비 투자계획에 대 하여는 주어진 자료내에서 추정하고 있으나, 차 입금 차입 및 상환계획은 고려하지 않았다. 기타 영업수익과 영업외수익은 총괄원가 추정과 동일 하게 2011년과 2012년 평균값 수준이 유지되는 것으로 가정하였다. 수입전망은 앞서 언급한 대 안별로 상이함으로 재정적자 규모 전망도 대안 별로 추정하였다.

[대안 1]의 경우에는 2018년까지 투자금액 증 가에 따라 재정적자 규모가 확대되는 것으로 추 정된다. 그러나 2020년까지의 하수도요금 현실 화에 따라 2019년부터는 재정적자 규모가 지속 적으로 감소하게 된다. 음(-)의 재정적자(즉, 재 정흑자)는 차입금 차입 및 상환액과 자기자본비 용을 고려하지 않은 결과이다. 추정된 하수부과 량과 원가정보 등의 추정자료를 신뢰할 수 있다 면, 2030 년 누적 재정적자는 130 억 원으로 예 상된다.

[대안 2]의 경우에는 2024년까지 투자규모에 따라 재정적자가 지속적으로 증가하지만, 2025 년 이후부터는 재정적자규모가 지속적으로 감소 할 것으로 추정되었다. 2030년 예상되는 누적 재정적자 규모는 1 조 6,924 억 원이다.

[대안 3]의 경우에는 물가상승률만큼 하수도 요금을 인상함에 따라 누적 재정적자 규모는 지 속적으로 급격히 증가할 것으로 예상된다. 2030
년 예상되는 누적 재정적자 규모는 9 조 7,703 억 원이다(대안별 재정적자 규모 전망의 결과 표 는 논문에 수록하지 않음. 상세한 결과는 서울시 (2014) 보고서 참조).

\section{3 대안별 비교}

대안 1 , 대안 2 와 대안 3 의 요금인상률, 현 실화율, 재정적자규모 등을 비교하면 Fig. 1과 같다. 대안 1 의 경우 2020 년까지의 하수도요금 현실화에 따라 2019년부터는 재정적자 규모가 지속적으로 감소하게 된다. 추정된 하수부과량 과 원가정보 등의 추정자료가 신뢰할 수 있다면, 2030년 누적 재정적자는 130 억 원이 예상된다. 대안 2 의 경우에는 2030년까지 하수도요금 현 실화에 따라 2025년부터 재정적자 규모가 지속 적으로 감소한다. 추정된 하수부과량과 원가정 보 등의 추정자료를 신뢰할 수 있다면, 2030년 누적 재정적자는 1 조 6,924 억원으로 예상된다. 대안 3 의 경우에는 물가상승률만큼만 하수도요 금을 인상함에 따라 누적 재정적자 규모는 지속 적으로 급격히 증가하여 2030년 예상되는 누적 재정적자 규모는 9조 7,703 억 원으로 추정된다.

대안분석에 따른 3 가지 대안들의 특징을 요약 하면 Table 8과 같다.

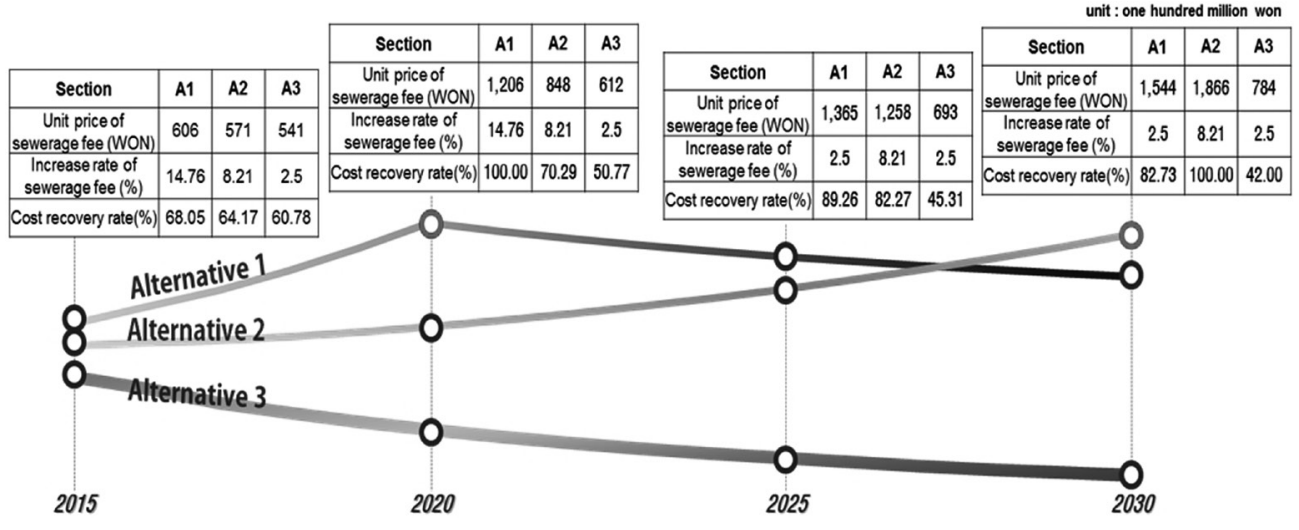

Fig. 1. Comparison of analysis results on 3 alternatives. 
Table 8. Summary of analysis results based on three alternatives

\begin{tabular}{|c|c|c|}
\hline Alternative 1 & Alternative 2 & Alternative 3 \\
\hline $\begin{array}{l}\cdot \text { Sewerage fee will increase annually by } \\
14.76 \% \text { from } 2015 \text { through } 2020 \\
\cdot \text { Scale of financial deficit will be enlarged } \\
\text { until } 2018 \text { with } \\
\text { - Increasing investment cost } \\
\text { - Scale of financial deficit will decrease } \\
\text { consistently after } 2019 \\
\text { - Accumulated financial deficit is esti- } \\
\text { mated as } 13 \text { billion won in } 2030\end{array}$ & $\begin{array}{l}\text { - Sewerage fee will increase annually by } \\
18.21 \% \text { from } 2015 \text { to } 2030 \\
\text { - Sewerage cost recovery rate will in- } \\
\text { crease to } 100 \% \text { until } 2030 \\
\text { - Scale of financial deficit will decrease } \\
\text { constantly after } 2025 \\
\text { - Accumulated financial deficit is esti- } \\
\text { mated as } 1,692.4 \text { billion won in } 2030\end{array}$ & $\begin{array}{l}\text { - Sewerage fee will increase as much as } \\
\text { the inflation rate } \\
\text { - Sewerage cost recovery rate is } 42.00 \% \\
\text { and cause of increase } 138.10 \% \text { in } 2030 \\
\text { - Accumulated deficit will increase con- } \\
\text { sistently } \\
\text { - Accumulated financial deficit is esti- } \\
\text { mated at } 9,770.3 \text { billion won in } 2030\end{array}$ \\
\hline
\end{tabular}

\section{4 하수도사업관련 수지개선 방향}

앞서 살펴본 것과 같이, 지속적인 누적 재정적 자가 예상되므로 정확한 자산평가와 원가행태의 분석을 기초로 총괄원가를 적정하게 계산하고, 하수도 사업 투자계획에 따라 요금 현실화를 추 진하는 것이 필요하다. 재정적자 부분을 보존하 기 위한 방법으로는 다음을 고려해 볼 수 있다.

- 국고 보조금의 확보

- 타회계(일반회계)의 전입금 확보

- 원인자부담금의 인상 및 빗물유출부 담금제 도입

- 외부 자금의 차입(기금 활용, 지방채 발행 등)

- 조직구성 및 운영의 효율화(민간투자 사업 모형의 고려)

- 기타 수익사업의 발굴

\section{4. 결 론}

본 연구를 수행한 연구진은 서울시 하수도사 업의 재정효율화를 위해 2020년까지 요금 현실 화를 실현할 수 있는 대안 1 의 시행을 권고한다. 단, 급격한 요금 인상으로 인한 저소득층이 받을 충격 완화를 위한 하수도요금 감면기준을 확대 적용하는 방안을 검토할 필요가 있다. 감면기준 의 확대방안과 감면에 따른 하수도세입의 감소 효과 예측에 관한 시나리오분석의 결과는 서울 시(2014)의 보고서를 참고할 수 있다.

하수도요금에 포함되어 있는 빗물처리 비용 에 대한 문제는 현행 제도하에서 하수도요금 인
상시 비용부담에 대한 형평성의 문제가 제기될 수 있는 반면, 공공비용의 부담확대와 원인자부 담 원칙에 의한 빗물요금제를 도입하는데 있어 서는 공론화가 필요한 사항이다. 그러나 2012년 2014년 하수도요금 인상으로 시민의 불만이 고조되어 있어 당분간 하수도요금 인상을 거론 하기에는 무리가 있어 보이므로 대시민 홍보 등 을 통하여 시의회, 시민 등과 공감대 형성으로 하수도요금을 인상하기 위한 분위기 조성이 우 선되어야 할 것으로 판단된다. 또한 2030하수도 정비 기본계획을 수립중인데, 본 연구결과를 참 고하여 재정계획 수립시 투자재원 확보를 위한 구체적인 하수도요금 현실화 방안이 강구되어야 할 것으로 판단된다.

\section{사 사}

본 연구는 2013년 2014년에 서울시 물관리 국의 지원에 의해 수행한 '하수도사업 재정운영 효율화 방안 연구'의 결과물의 일부를 발췌한 것 으로서 이에 감사를 드립니다.

\section{References}

Ministry of Security and Public Administration (2014). Local Public Enterprise Act and Enforcement Ordinance.

Ministry of Security and Public Administration (2013). Financial Accounting Rules of Local Government.

Kang J. (2012). "Problems and issues of Local Public corporation system”, Kyunghee 
Law Studies, 47(1), 98-130.

Korea Waterworks Management Institute (2013). Report on General Cost Estimating of Sewerage, Seoul Metropolitan Government.

InfraGuide (2006). Water and Sewer Rates : Full Cost Recovery, A Best Practice report published by InfraGuide, Ottawa, Canada.

UAPS(1999). Governmental Accounting Standards Board Statement No. 34.

Jeong, S., Cho, S, Hyun, D., and Bae, S. (2012). "Factors affecting local water supply costs and water prices in Korea”, Local Administration Studies, 26(3), 287-310.

Francois, D., Correlje, A. F., and Groengewegen P. M., (2010). "Cost recovery in the water supply and sanitation sector; a case of competing policy objectives?”, Utility Policy, 18, 135-141.

Han, I. (2009). "Performance and tasks of management revolution by reorganizing local public enterprises", Korean Assoiciation of Local Public Enterprises, 5(2), 83-102.

Hansen, A. (2014). "What is behind the water price in Denmark - a comparison between countries", Proceedings of European Utilities Management Conference, 14-16 May, 2014, Oslo, Norway, International Water Association.
Labre, J. (2014). "The cost recovery principle: what clarification are needed?", Proceedings of European Utilities Management Conference, 14-16 May, 2014, Oslo, Norway, International Water Association.

OECD (2009). Managing Water for All - An OECD Perspective on Pricing and Financing.

Seoul Metropolitan Government (2012). Ordinance of Sewerage Use.

Seoul Metropolitan Government (2009). Sewer Rehabilitation Master Plan of Seoul Metropolitan City.

Seoul Metropolitan Government (2014). A Study of Financial Operations Efficiency for Sewerage Project. 51-611000-000866-01.

van Dijk, M. P., Etajak, S., Mwalwega, B., and Ssempebwa, J. (2014) "Financing sanitation and cost recovery in the slums of Dar es Sallam and Kampla”, Habitat International, 43, 206-213.

Zocchi, R. (2014). "3Ts approach for an effective use of the pricing policies", Proceedings of European Utilities Management Conference, 14-16 May, 2014, Oslo, Norway, International Water Association. 